\title{
Administration of Zakat on Wealth in Maldives
}

\author{
Dr Aishath Muneeza \\ International Centre for Education in Islamic Finance (INCEIF), \\ The Global University of Islamic Finance, Malaysia
}

\begin{abstract}
:
For Muslims zakat is obligatory and different jurisdictions in the world have different mechanisms to administer it. Maldives is a hundred percent Muslim country and zakat administration in the country is unique. As such the objective of the paper is to discuss the zakat administration in Maldives with special reference to zakat al mal and to discuss the challenges facing the existing way of zakat administration. The paper also includes ways to overcome the challenges. No literature on this area in Maldives could be found and as such reference to primary materials such as unpublished statistics, reports, brochures have been made. It is hoped that this paper will encourage further research on this area in Maldives.
\end{abstract}

Paper type: Literature Review

Keywords: Zakat, Maldives, Zakat al mal, Zakat Collection and Distribution, Islamic Finance, Zakat Administration 


\section{Introduction}

Maldives is a Muslim country that is situated in the Indian Ocean. The country consist 1190 islands (Bell, 1940) and the main source of income to the country is tourism (Maldives Inland Revenue Authority, 2017). Guided by the tenets of Islamic faith, the Maldives financial sector has been undergoing a series of changes in recent years. Remarkable changes in Maldives include Islamic banking regulation that came into force in 2011 and the first Islamic bank in the country -- Maldives Islamic Bank -- was established in the same year (Sambajee and Dhomun, 2015).

Zakat is the third Pillar of Islam. Often it is translated as alms or poor-due; however, zakat literally means purification, growth, and blessing. Zakat is also the first pillar of Islamic economic system. Zakat is portion of a man's wealth which is designed for the poor (Wahab and Abdul Rahman, 2011). Zakat is an obligation in respect of funds paid for a specified type of purpose and for specified categories. Zakat refers to the sum of money that Muslims who are mentally stable and financially able need to contribute in order to support specific groups of people according to eight categorizes stated in the Quran in Surah At-Taubah verse 60 (Wahab and Abdul Rahman, 2011; Yusuf and Derus, 2013). The contemporary practice of zakat management differs from country to country with respects to their locality (Yusuf and Derus, 2013).

Zakat plays an important role in Muslim society in both spiritual and material dimensions. Verse 9:103 of the Quran illustrates the spiritual dimension of zakat. According to Al Qardawi (2005), the word zakat refers to the determined share of wealth prescribed by Allah to be distributed among deserving asnaf (zakat recipients). There are two types of zakat: zakat on wealth which is paid at any time during the year when possession of the zakatable assets for one hijrah year is fulfilled and the market value of the zakatable asset reaches 86 gram of gold; and zakat fitrah which is paid in the month of Ramadan before Eid prayers.

The recipients of zakat al mal have been specified in Quran in Surah At-Taubah verse 60. It is not necessary to distribute equally money received as zakat among these eight categories (eight asnaf) Imam Malik and Abu Hanifah are of the view that the distribution is not necessary to all the eight asnaf. The distribution of zakat is usually based on the judgment of zakat administrators and discretion to the asnaf in their locality (Yusof and Derus, 2013). For instance, zakat collection in Malaysia is governed by state affair but Muslims are left to pay zakat based on their devotion to their religion, rather than compulsion (Yusof and Derus, 2013).

The objective of this paper is to describe the zakat administration in Maldives with reference to the historical development of it, find out the challenges facing it and recommend solutions to overcome these challenges. As such this paper will give an overview of zakat collection and payment mechanism found in Maldives. It is imperative to state that it is hard to find literature on this subject and as such, primary sources such as Zakat Fund Statement and Agreements have been referred to. It is hoped that this paper will motivate more research on the subject in Maldives.

International Journal of Management and Applied Research, 2017, Vol. 4, No. 1 


\section{History of Zakat Collection \& Distribution in Maldives}

In 1983, under the leadership of Former President Uza. Maumoon Abdul Qayoom, the first office to deal with matters related to zakat was opened and Sheikh Usman Abdulla was appointed as the head of the office. A weekly radio program was also made to create awareness among the public on zakat related matters. Also a special book on zakat written in Dhivehi language was published by the President Office. Before the establishment of Zakat Office, the norm was only to pay zakat fitr. However, public awareness about zakat on wealth was created after the establishment of zakat office. In the early years of operation of Zakat Office about Maldivian Rufiyaa Fifty was collected annually as zakat on wealth.

To administer the zakat related technical matters, Zakat Committee was formed and the mandate of this committee included announcing the nisab amount in Maldivian rufiyaa after considering the rate of silver. Discussions were undertaken in this Committee to identify the nisab limit in Maldivian Rufiyaa. It was agreed to utilize the comparative nisab in silver as the official amount of nisab in Maldivian Rufiyaa. The price of silver in the world market is reviewed every six months and the equivalent amount in Maldivian Rufiyaa is published as the nisab for Maldives.

On $11^{\text {th }}$ November 1993, the operation of the Zakat Office was under the purview of Ministry of Justice and Islamic Affairs. On $6^{\text {th }}$ November 1996, the Zakat was brought under Supreme Council for Islamic Affairs. The fi sabilillahi component of the zakat distribution was administered via government ministries. The health component was administered by Ministry of Health while the education component was handled by Ministry of Education. Assistance under education, such as text books and uniforms were provided to the needy citizens. In addition, debtors and the poor were assisted via Zakat Office as cash benefits. In 2008, the Supreme Council for Religious Affairs, was transformed to Ministry of Islamic Affairs and all mandates of Zakat Office was transferred to the Ministry.

Under the leadership of the Minister of Islamic Affairs, Dr Abdul Majeed Abdul Bari, numerous productive reforms to the administrative structure for zakat distribution were developed. On $3^{\text {rd }}$ February 2010 in collaboration with the Ministry of Finance and Treasury, as per the Public Finance Act 2006, a special trust fund for zakat, namely "zakat fund" was established. The zakat fund is headed by a Committee which comprises of representatives from key stakeholder agencies. This Committee is mandated to identify the criteria which zakat distribution is made as per Islamic law. They also identify the focus areas as per broad communal benefits and amounts that can be spent under the fisabilillahi portion of the zakat.

The Ministry of Islamic Affairs is responsible for collection of zakat from all inhabited islands in Maldives, including Male, the capital of the country. It also distributes the zakat as per categories stated under Islamic law.

In 2012, under the leadership of the Minister of Islamic Affairs, Dr Mohamed Shaheem Ali Saeed, further developments and refinements were introduced to the zakat

International Journal of Management and Applied Research, 2017, Vol. 4, No. 1 
administration process after thorough legal and shariah research (Latheef, 2015). Guidelines for the beneficiaries of zakat under Islamic law and the scope of distribution of zakat were developed. Subsequently, a bill was drafted on zakat which incorporated further reform to the incumbent regulation on zakat distribution. The Bill constituted of procedures to be followed in zakat distribution, identification of beneficiaries, oversight on zakat collection and distribution as well as the facilitators for zakat administration, their roles and responsibilities. The Ministry of Islamic Affairs continues the effort to introduce and pass Zakat Bill in order to govern and manage the matters related to zakat as practiced in other Muslim nations.

In 2012, a Shariah Advisory Committee consisting of religious scholars was created as an advisory body. The Shariah Committee is mandated to advise the zakat unit as well as the zakat committee on matters pertaining to zakat in Islamic law and shariah opinion. The members of the Committee are appointed by the Ministry of Islamic Affairs.

In 2016, the operation carried out by Ministry of Islamic Affairs in the collection of Zakatal-mal was handed over to Maldives Inland Revenue Authority (MIRA). However, the Ministry of Islamic Affairs continues to collect Fitr Zakat (Maldives Inland Revenue Authority, 2016).

\section{Governance Structure of Zakat al Mal Administration in Maldives}

In Maldives, Zakat administration has been carried out by the Ministry of Islamic Affairs as well as Maldives Inland Revenue starting from 2016. Zakat fund would be administratively handled by the Zakat Committee. All funds received as zakat will be collected and kept in zakat fund. Zakat fund is a Trust Account which has been created under the discretionary power vested to the Minister of Finance and Treasury under section 26 of the Public Finance Act 3/2006. Zakat Fund Trust Account was established on 3rd February 2010.

According to the Trust Statement of the Zakat Fund, the name of the trust account formed shall be zakat fund and Zakat money received shall be kept in the Trust account until it is distributed in the format in schedule 1 of the zakat fund trust statement. Schedule 1 of the Zakat Fund Trust Statement states that the categories to which zakat money shall be distributed is poor, miskin (needy), amil, muallafatu quloobuhum, debtors, fi sabilillahi, ibn sabeel and freeing salves. Zakat Fund shall be governed in accordance with the Public Finance Regulations. Money deposited to the zakat fund shall be the money paid by the citizens of Maldives and the corporations as zakat and there is no ceiling to the money deposited to the account as zakat money received by individuals and corporates from the day off opening of this account and until it is closed can be kept. All expenses that has been made in accordance with schedule 2 of the Zakat Fund Trust Statement is authorized. According to schedule 2 of the Zakat Fund Trust Statement (first amendment effective from $15^{\text {th }}$ May 2013) expenses authorized from the account are:

a. Eight categories of people mentioned in the Quran 9:60 (The Masakeen - 'the destitute', Fuqaraa - 'the needy or poor', Amil' Zakah - 'the alms collectors', Fi

International Journal of Management and Applied Research, 2017, Vol. 4, No. 1 
sabi 'Lillah - 'in the path of God', Gharimun - 'people burdened with debt', Ibn as'Sabil - 'the wayfarers', Riqab - 'people in bondage or slavery', Mu'Allaf 'those who have inclined towards Islam')

b. Medical expenses of poor

c. People inflicted with calamities

d. Bank Commission incurred while sending zakat money

e. Spread Quranic knowledge and t conduct Quran competitions

f. To conduct religious awareness activities

g. To build human capital required for nation development and to educate people in local \& international universities

h. Religious materials creation \& proof reading related expenses

i. Expenses incurred in conducting different educational courses related to religion

j. Expenses incurred in training of Quran and Islam teachers and Imam training courses, under taker courses and other religious courses

k. Expenses related to conducting of Quran classes

1. To build worship places in schools, build ablution facilities and other services related to it

$\mathrm{m}$. To spend on expenses related peace and national security of the country and national related matters

n. Give wages to Taraweeh prayer imams during Ramadhan

o. To people inflicted with sudden calamities

p. Expenses incurred by educating of children and people with special needs and spending on necessities of these category of people

q. Expenses incurred in zakat money record keeping and consultancy services

r. Administrative expenses of the zakat fund and investment related activities of the fund

If for any reason, the Zakat Trust Account is closed, if there is a balance in the zakat fund when closing it, the balance shall be deposited to the consolidated revenue account. An annual report on the zakat money received and disbursed shall be prepared once a year by the Zakat Unit and it shall be approved by the Zakat Committee. This report shall be prepared within one month of the end of the financial year. Within three months of the end of each Gregorian year Annual Report of the zakat fund and the financial statements of the previous year shall be gazette in the National Gazette or in the daily newspapers published and it shall also be published in the website of the Ministry of Islamic Affairs. Zakat Trust Account shall be closed on the date in which the Minister of Finance and Treasury decides after he receives a request to close the account from the Ministry of Islamic Affairs or if the Minister of Finance \& Treasury decides to close it and order so, if he finds that the purpose for the creation of the fund is not achieved.

A Shariah Advisory Committee is also formed to assist the Zakat Committee with the shariah matters. Other than these two committees in 2014, a Zakat Scholarship Committee is formed to award scholarships to needy students. The governance structure of zakat in Maldives can be illustrated in Figure 1:

International Journal of Management and Applied Research, 2017, Vol. 4, No. 1 
Figure 1: Governance Strucute of Zakat in Maldives

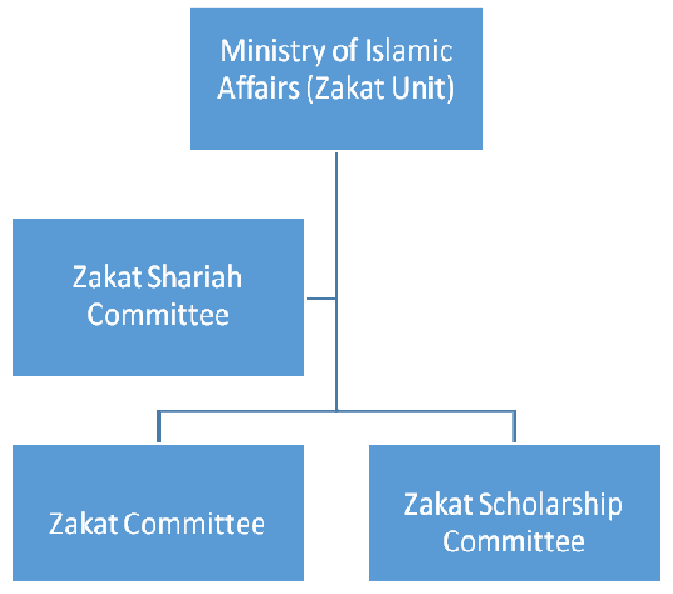

Zakat Committee is a Committee established to advice on matters related to zakat fund; especially on spending of money allocated to fi sabilillah. The composition of the Committee includes expertise from various ministries of the government. The scopes of the work of Zakat Committee are as follows:

a. Determining the amount to be distributed to the zakat money receiving categories mentioned in the Quran

b. Investigating the forms received by debtors to receive zakat money and determining whether those debts have riba or not

c. Debt covered by zakat money are those people who incur debt due to natural disasters and those who has taken debts to fulfill their necessity and is unable to pay off the debt

d. Due to sudden accidents if one has to be transferred to a hospital in another island, based on the doctor's recommendations to transfer, whether zakat money could be utilized for this purpose and if zakat money could be used, the amount and the basis shall be prescribed by the Committee from the portion allocated to ibn sabeel and the Committee shall give recommendation to Ministry of Islamic Affairs to implement it

e. Those unable to pay hospital bills in Maldivian hospitals or international hospitals or those with diseases like cancer, kidney failure and people who has to do by pass can be based on the circumstance be given zakat assistance

f. Those travelers who has been inflicted with calamities while travelling can be given zakat assistance from the portion of fi sabilillahi and the guidelines to give such assistance shall be laid down by the Committee

g. Helping the Ministry of Islamic Affairs to enforce the decisions of the Committee

h. Checking on the progress of implementation of decisions taken by the Zakat Committee by the Ministry of Islamic Affairs 
Zakat Committee has the power to decide the ways in which funds in fi-sabilillahi portion can be distributed and the amounts to be distributed. Ministry of Islamic Affairs shall distribute zakat in accordance with the decisions taken by the Zakat Committee. The Committee can do research and seek expert opinion on issues put forth to the Committee for deliberations.

Zakat Shariah Advisory Committee shall be the shariah advisory body giving shariah rulings on matters relating to zakat to the Ministry of Islamic Affairs, Zakat Unit and the Zakat Committee. The scope of work of the Shariah Committee includes ensuring that the matters related to zakat are conducted in accordance with shariah.

A special agreement is signed between Ministry of Islamic Affairs and National Social Protection Agency (NSPA) to give zakat fund medical assistance to needy. To provide medical assistance to needy under one-roof, the Ministry delegated the task to NSPA. The main points agreed in the Agreement are:

1. Providing medical assistance to needy in compliance with the rules and guidelines of NSPA. Priority shall be given to hear patients, kidney, liver problem patients, cancer patients, purchase of artificial limbs, medicines for chronic illnesses and lab investigations.

2. Segregation in record keeping of zakat fund money disbursed to NSPA

3. Within 15 days after the end of each month, NSPA shall submit a report to the Ministry notifying the expenses and the balance of funds given

4. If the assistance is given via Zakat fund, the person who got assistance shall be notified in writing that the assistance is given by the zakat fund

5. Assistance and zakat fund shall not be given for the following purposes:
a) Abortion
b) Cosmetic Surgery
c) Sex change operations
d) Artificial insemination of child \& conducting contraceptive operations
e) Purchase of human organs
f) Other things unauthorized from zakat fund

6. If there is doubt as to whether a certain expense could be made via zakat fund money, than the clarification on that matter shall be obtained by the Ministry.

7. Zakat money shall be spent in accordance with the Public Finance Act 3/2006.

8. If a medical assistance is given by another scheme of the government and the money given under the scheme is insufficient, zakat money could be given to settle the uncovered expenses under the government scheme. 
9. If Ministry wants to check on the utilization of the zakat money, than NSPA shall make such arrangements for the inspection.

10. If there is a breach to any terms and conditions of this agreement, Ministry has the power to terminate the agreement.

11. Zakat Medical Assistance via NSPA shall commence from $2^{\text {nd }}$ January 2013 and from February to the end of January will be considered as a year.

\section{Statistics on Zakat Collection and Distribution in Maldives}

Zakat collection in Maldives is made by Ministry of Islamic Affairs for Male' City and by the Atoll and Island Councils for other islands of the country. It is not mandatory to disclose the zakat payers' information to the authority (ies) and the zakat payer's information are not recorded. When the zakat payment is made a receipt is given as a proof of payment to the payer. Zakat payment is voluntary and it is up to the payer to decide whether he is eligible to pay or not and whether he is going to pay or not.

As for the payment of zakat al fitr, the payment can be made via sms and the money could be deposited to the bank accounts specified by the Ministry of Islamic Affairs. In the distribution of fitr zakat all money received from these means will be distributed in Male' City while all collected by Atoll and Island Councils will be distributed in respective islands among the people registered as poor or faqeer.

Zakat al mal collected by the Atoll and Island Councils will also be deposited to the public account which will eventually be deposited to the Zakat Public Trust Account. However, these is no mechanism except to rely on the copy of the receipts received from Atoll and Island Councils when cross verifying the money deposited to the public account. It is recommended to use a special software for this purpose so that in real time the Ministry of Islamic Affairs will know the money received by the Atoll and Island Councils and will have a mechanism to verify that the all money received are deposited to the Zakat Public Trust Account.

While disbursing the zakat money the paramount consideration is given to distribute a large amount to the faqeer and miskeen as they are the first two priority groups stated in the Quranic verse regarding the recipients of zakat. The rest of the disbursements are made by the Zakat Committee after considering the cases they receive requesting for zakat money. Individuals and government entities could apply to receive zakat money and even Ministry of Islamic Affairs can request to allocate zakat money for various purposes it deems fit to utilize zakat money. However, in all cases, the ultimate decisions on disbursements of the zakat money will be taken by the Zakat Committee, based on careful evaluation and assessment. On case by case basis, after deliberation made between the members, a vote will be taken to reach the final decision. This is the reason why the areas stated in Fi Sabilillah portion differes from year to year as illustrated in the Tables below. Also the zakat money can be carried forward to the next year if the money is not fully utilized as expected and budgeted by the Zakat Committee. In the beginning of every year,

International Journal of Management and Applied Research, 2017, Vol. 4, No. 1 
the Zakat Committee will endorse allocation areas and amount of money that will be utilized for each portion. This is the reason why the amount distributed in years shown in the table are more than the collected amount of zakat.

Figure 2 illustrates the statistics on zakat collection (including fitr zakat \& sadaqat) in Maldives in the recent years. It is evident that zakat payment has been increased from 2012 to 2014, which indicates a growing public awareness with respects to zakat (Sun Media Group, 2015).

Figure 2: Zakat Collection (including Fitr Zakat \& Sadaqat) in Maldives (in MVR)

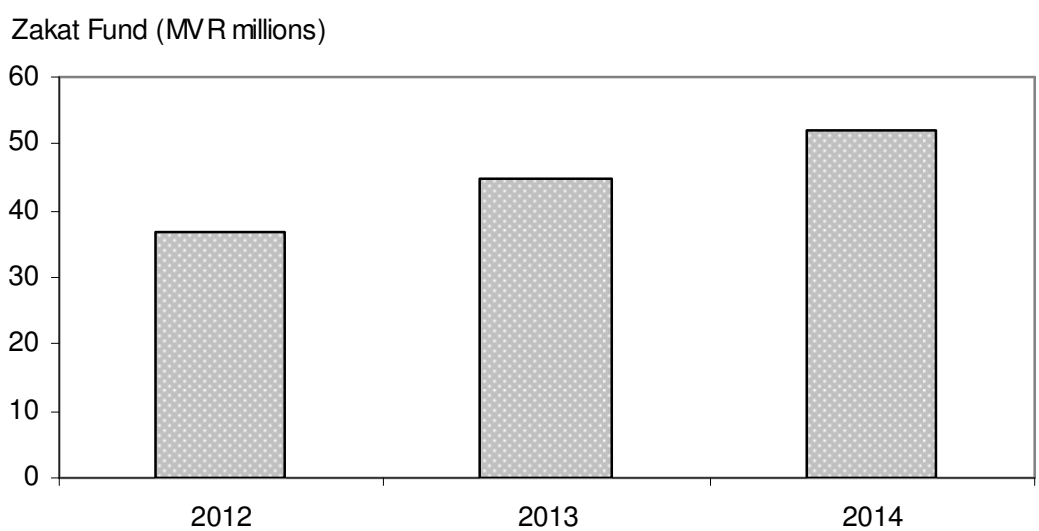

Source: Sun Media Group, 2015

Expenses in relation to fi Sabilillah portion in Maldives are allocated for different purposes where the public will be benefited. Tables 1 illustrates the different areas in which the fi Sabilillah portion of zakat money are allocated in Maldives from 2012 to 2014. It also indicates that expenses made in relation to fi Sabilillah grew, corresponding to the steady increase of zakat amount received from 2012 to 2014.

Table 1: Expenses made in relation to fi Sabilillah from 2012 to 2014

\begin{tabular}{|c|c|c|c|}
\hline Descriptions & 2012 & 2013 & 2014 \\
\hline For teachers teaching special need children & $300,000.00$ & $141,219.92$ & $680,000.00$ \\
\hline Expenses in conducting National Quran Competition & $626,558.03$ & $991,829.80$ & - \\
\hline $\begin{array}{l}\text { Expenses incurred in conducting religious awareness } \\
\text { programs }\end{array}$ & $17,170.00$ & $1,979,470.66$ & $8,364,006.86$ \\
\hline Expenses incurred in conducting courses to train & & & \\
\hline $\begin{array}{l}\text { Quran \& Islam teachers, Imam courses and funeral } \\
\text { rites related courses }\end{array}$ & - & $4,293,284.74$ & - \\
\hline For higher education (students studying in Maldives) & $1,000,000.00$ & $8,000,000.00$ & - \\
\hline For higher education (students studying abroad) & $1,000,000.00$ & - & - \\
\hline
\end{tabular}

International Journal of Management and Applied Research, 2017, Vol. 4, No. 1 
Publication of religious materials/books

Expenses to conduct religious courses

Expenses to conduct private Quran classes

Build prayer rooms in schools

Maintain national security

To develop praying places in islands in general

To promote Quranic knowledge in a wider manner

Facilitate the establishment of Islamic University

Person conducting taraweeh prayer who are hafiz

TOTAL

$\begin{array}{rrr}268,052.00 & 544,034.89 & 157,320.00 \\ 29,164.78 & - & 22,656.00 \\ 13,682.00 & 7,367.00 & - \\ 17,235.00 & 814,752.83 & 1,964,891.43 \\ 46,684.05 & - & - \\ - & - & 724,239.18 \\ - & - & 6,772,725.51 \\ - & - & 349,001.12 \\ 799,356,52 & 814,752.83 & 1,417,365.68 \\ \mathbf{3 , 3 1 8 , 5 4 5 . 8 6} & \mathbf{1 7 , 5 8 6 , 7 1 2 . 6 7} & \mathbf{2 0 , 4 5 2 , 2 0 5 . 7 8}\end{array}$

Source: Ministry of Islamic Affairs

\subsection{Zakat and Tax}

Section 23 of Business Profit Tax Regulation (Regulation Number 2011/R-35), formulated under the Business Profit Tax Act (Law Number 5/2011) and published in the Government Gazette on18th of August 2011 deals with zakat al-mal as tax deductable income. This section states that payments made as zakat al-mal may be deducted in calculating a Person's taxable profits provided that the Person possesses a receipt that states that the zakat was paid to the relevant government authority. At the moment in Maldives, there is no income tax.

\section{Challenges faced in Zakat Collection and Distribution in Maldives}

Though Maldives is a hundred percent Muslim country, the operation of zakat system parallel to the tax system creates problem and apart from this, many challenges are faced in zakat collection and distribution. This section of the paper will look at the challenges faced in zakat collection and distribution in Maldives.

\section{Lack of Statutory powers}

Proper legislation to govern the matters related to zakat is required. For tax administration special statutory powers are granted by way of legislations and this is something that lacks in zakat administration in Maldives. Special statutory powers are required in order to implement mandatory collection of zakat in the country. With this regard in 2014, Islamic Development Bank and Islamic Research and Training Institute have assisted the country to draft a sophisticated zakat law and the bill they enacted is pending with the Attorney General's Office. Information collection and record keeping of the zakat payer and enforcement actions that could be taken against individuals and corporations defaulting to pay zakat are important aspects that shall be covered in the legislation.

\section{Lack of Education and Awareness}

International Journal of Management and Applied Research, 2017, Vol. 4, No. 1 
Knowledge in Shariah-compliant financial products as well as expertise in Information Technology is important to the efficiency of Zakat institutions (Wahab and Abdul Rahman, 2011). However, Morrison (2013) reports that there is a skill shortage in Maldives bank employees and Shariah advisers. Additionally, many Muslims lack adequate understanding of zakat collection since its rules, principles, and calculation are rarely delivered by religious teachers (Salim, 2008). For that reason, zakat is often referred to as the 'forgotten pillar' (National Zakat Foundation, 2016), highlighting the need to educate both zakat administrator and payer.

\section{Lack of Sophisticated IT Infrastructure}

As Wahab and Abdul Rahman (2011) suggested, the use of IT could improve the efficiency and productivity of zakat administration and enhance convenience for zakat payers at the same time. In Maldives, however, all paperwork related to zakat is handled manually at the time of this research, which results in inefficient use of time and resources. For example, if a needy or poor Muslim wish to receive zakat, he or she needs to present National Identity Card for the purpose of verification; this presents a problem as it is difficult to detect duplication of Identity Cards in a timely manner. In 2014, the Ministry of Islamic Affairs handed over a project to National Center for Information Technology (NCIT) in developing software to manage zakat collection and distribution (Island Broadcasting Company, 2015). This indicates a good start as this might open doors to adopt information technology to ease zakat administration. Therefore it is recommended to manage the collection and distribution of Zakat nationwide using an efficient computerized system that can manage, track and report processes in real-time. Zakat Management System shall provide online services using web-portals to collect and distribute Zakat via agented outlets. The system can be an extension to the official website of zakat institutions. The incorporation of modern technology could simplify the zakat collection process so that zakat payers could make payment in hassle-free and timely manner.

4. Lack of Coordination between Island Councils \& Central Zakat Collection and Disbursement Unit in the Ministry of Islamic Affairs

At the moment due to geographical nature of the country and the lack of availability of adequate banking facilities in all islands of Maldives, zakat collection needs to be done via the assistance from Atoll and Island Councils. It is not easy to get daily information of collection of zakat from these entities and as a result at the end of the year, the Ministry of Islamic Affairs has little means to verify the actual amount received and the actual amount deposited to the Zakat Public Trust Account. The lack of internal coordination between zakat agencies and councils inevitably leads to duplication of data as well as low level of effectiveness. In reference to Halimatusa'diyah (2015), such coordination problems may be better addressed by creating or developing zakat institutions, which serve to coordinate the operations of zakat collection and distribution from multiple units. From managerial perspective, it would be better if each party has a clear map of their contribution to the common goal, that is, to attain socio-economic justice.

International Journal of Management and Applied Research, 2017, Vol. 4, No. 1 
5. Governance Issues

Good governance is crucial to an effective organisation because it mediates varying interests to reach a consensus on the best interest of stakeholders and defines policies accordingly (Taylor, 2000). According to Raimi et al. (2014), the root cause of poverty in the Muslim majority nations is related to ineffective governance policies which caused widening income inequality. Hence, the dynamics of Islamic financial and capital markets need to be balanced with wealth distribution in order to achieve socio-economic justice, the main objective of zakat. The governance of zakat administration here refers to the governance structure and mechanism of zakat collection and distribution to ensure that the decision making process is accountable, transparent, and fair (Wahab and Abdul Rahman, 2011). To create a sustainable wealth distribution in Maldives, there is a need to resolve the governance and regulatory issues. The country lacks a governance framework to supervise and regulate zakat administration. Though Islamic Banking Regulations took effect since 2011, issues such as debt management and zakat administration are not dealt with (Muneeza, 2014), thereby inhibiting the growth of Islamic finance in the country and attainting socio-economic justice.

\section{Introducing Easy Methods to Pay Zakat}

At the moment the only zakat al mal payment method available to zakat payers is by physically going to the Ministry of Islamic Affairs if in Male'City and if in other islands, physically going to the Atoll/Island Councils. Zakat al Fitr payments can be made via sms for mobile phone users using Unstructured Supplementary Service Data (USSD) (mBillionth Award, 2016). Zakat payers can also make the payment using cheque or cash via the counter of the Ministry or respective Councils of the islands. Alternatively, the eligible Muslims could pay at the counters of Allied Insurance Islamic Window (Allied Insurance Company, 2015). Zakat institutions can play an active role in promoting zakat payment by adopting a multichannel approach, allowing eligible Muslims to make zakat payment in various ways, including postal order, ATM, salary deduction, or perhaps street collection. It is highly likely that more zakat payers would be benefitted as the options of making zakat payment increases.

\section{Need for Introduction of Sustainable Social Assistance Programs}

From the pattern of zakat distribution of the past three years in Maldives proves that there is need to introduce sustainable social assistance programs that will be continued every year. The current trend is that the zakat distribution is made on ad hoc basis when the request is made and if the request is taken to the zakat committee. This is the main reason why the zakat carry forward amounts are huge. According to Shaikh (2017), zakat distribution can be divided into two forms: the first type is financial assistance for those who are not productive as they are not capable of working, and the second type is support services including training, healthcare, insurance, and equipment to enable the recipients to carry out activities that can support their livelihood, sustain themselves and help them get out of poverty. As such, there is need to concentrate on these two areas in an effective manner. The impact of the programs on the recipients' achievements after receiving the capital assistance need to be 
carefully studied as this will help to understand the effectiveness of the zakat to the society and will also help to understand on areas that needs improvement. The Empowerment Zakat Recipient Program launched on the 5th of November 2007 by Majlis Ugama Islam Brunei (MUIB) is a good example of how zakat money could be used in a sustainable manner. This program provided training for the poor and needy so that they can acquire skills and have opportunities to get jobs or start their own businesses.

\section{Conclusion}

Zakat is a compulsory act of worship for all Muslims. Two parallel systems, a conventional tax system and a zakat system coexist in Maldives (Maldives Inland Revenue Authority, 2016).

With the assistance from Islamic Development Bank (IDB) \& International Research and Training Institute (IRTI), the country has developed a zakat bill, which will become a law soon. However, to have an effective zakat collection and disbursement system in the country, it is important to resolve the challenges, which includes regulatory and governance issues, skills shortage and inadequate knowledge of zakat payment, coordination problem, limited payment methods, lack of sophisticated IT infrastructure, and also the need for introduction of sustainable social assistance programs. Then only, an effective system for zakat management can be placed in the country. It is anticipated that the suggestions and recommendation made in this paper will assist to develop a sustainable and effective system for zakat management in Maldives.

\section{References}

1. Allied Insurance Company (2015), You can now pay Zakat-al-Fitr at Ayady Takaful (Allied Insurance Islamic Window) Counters, [Online] available from: https://allied.mv/news-updates/Pay-Zakat [accessed on 1 Feb 2017].

2. Al-Qardawi, Y. (2005), Fiqh Al Zakah (Volume II): A Comparative study of Zakah, regulations and philosophy in the light of Qur'an and Sunnah, translated by Dr. Monzer Kahf, King Abdulaziz University: Scientific Publishing Centre.

3. Bell, H.C.P. (1940), The Maldive Islands, Monograph on the History, Archaeology and Epigraphy. Colombo: Ceylon Government Press. Reprinted in 1985. Male: National Centre for Linguistic and Historical Research.

4. Business Profit Tax Act (Law Number 5/2011)

5. Business Profit Tax Regulation (Regulation Number 2011/R-35)

International Journal of Management and Applied Research, 2017, Vol. 4, No. 1 
6. Halimatusa'diyah, I. (2015), "Zakat and Social Protection: The Relationship Between Socio-religious CSOs and the Government in Indonesia", Journal of Civil Society, Vol. 11, No. 1, pp. 79-99. https://doi.org/10.1080/174486899.2015.1019181

7. Island Broadcasting Company (2015), "\$90,000 arranged to develop Zakat software", $V$ News [Online] available from: http://www.vnews.mv/39354 [accessed on 1 Feb 2017].

8. Latheef (2015), "Govt's most hopeful minister, Dr. Shaheem resigns", Miadhu Daily [Online] available from: http://www.miadhu.mv/article/en/2269 [accessed on 1 Feb 2017].

9. Maldives Inland Revenue (2016), Zakat al-mal to be collected by MIRA, [Online] available from:

https://www.mira.gov.mv/eNewsletter/MIRApostArticles.aspx? articleid=15\&block=4 [accessed on $1 \mathrm{Feb} 2017$ ].

10. Maldives Inland Revenue (2017), Quarter 4 2016, [Online] available from: http://www.mira.gov.mv/reports/16Q4\%20English.pdf [accessed on 1 Feb 2017].

11. mBillionth Award (2016), Developing a solution for Dhiraagu customers to pay their zakat via USSD/SMS, [Online] available from: http://mbillionth.in/milestones/mbillionth-2010/winners-2010/developing-a-solutionfor-dhiraagu-customers-to-pay-their-zakat-via-ussdsms/ [accessed on 1 Feb 2017].

12. Morrison, S. (2013), "Islamic Banking in Maldives", Harvard Asia Quarterly, Vol. 15, No. 3/4, pp. 47-55.

13. Ministry of Islamic Affairs (n.d.), Unpublished Statistics.

14. Muneeza, A. (2014), "Maldives: the Struggle for New Hope in a Garland of Palm-Clad Islands", in: Thiagaraja, S.; Morgan, A.; Tebbutt, A. Chan, G. (Ed), The Islamic Finance Handbook: A Practitioner's Guide to the Global Markets, Singapore: John Wiley \& Sons.

15. National Zakat Foundation (2016), Introduction: National Zakat Foundation, [Online] available from: https://nzf.org.uk/resources/NZF_IntroFlyer.pdf [accessed on 1 Feb 2017].

16. Public Finance Act 3/2006

17. Raimi, L.; Patel, A. and Adelopo, I. (2014), "Corporate social responsibility, Waqf system and Zakat system as faith-based model for poverty reduction", World Journal of Entrepreneurship, Management and Sustainable Development, Vol. 10, No. 3, pp.228 - 242. https://doi.org/10.1108/WJEMSD-09-2013-0052

18. Salim, A. (2008), Challenging the Secular State: The Islamization of Law in Modern Indonesia, University of Hawaii Press. 
19. Sambajee, P. and Dhomun, M. Z. A. (2015), "Government and SMEs in the Maldives and Mauritius", International Journal of Entrepreneurial Behavior \& Research, Vol. 21, No. 6, pp.778 - 795. https://doi.org/10.1108/IJEBR-12-2014-0230

20. Shaikh, S. A. (2017), "Poverty alleviation through financing microenterprises with equity finance", Journal of Islamic Accounting and Business Research, Vol. 8, No. 1 pp. - https://doi.org/10.1108/JIABR-07-2013-0022

21. Sun Media Group (2015), "Zakat Fund receives over MVR 70 million”, SunOnline, [Online] available from: http://english.sun.mv/27077 [accessed on 1 Feb 2017].

22. Taylor, D.W. (2000), "Facts, myths and monsters: understanding the principles of good governance", The International Journal of Public Sector Management, Vol. 13 No. 2, pp. 108-21. https://doi.org/10.1108/09513550010338755

23. Wahab, N. A. and Abdul Rahman, A. R. (2011) "A framework to analyse the efficiency and governance of zakat institutions", Journal of Islamic Accounting and Business Research, Vol. 2, No. 1, pp. 43 - 62. https://doi.org/10.1108/17590811111129508

24. Yusuf, M. O. and Derus, A. M. (2013), "Measurement model of corporate zakat collection in Malaysia: A test of diffusion of innovation theory", Humanomics, Vol. 29, No. 1, pp. 61 - 74. https://doi.org/10.1108/08288661311299321 